\title{
THE EFFECT OF TEACHING STRATEGIES AND SELF REGULATION ON STUDENTS'READING COMPREHENSION
}

\author{
Irmayanti \\ Didik Santoso \\ Rahmad Husein
}

Diterima September 2017; Disetujui Oktober 2017; Dipublikasikan Desember 2017

\begin{abstract}
The objectives of this experimental research were to find out whether: (1)The students' achievement in reading comprehension taught by using Read, Ask, Put, and Paraphrasing (RAPP) strategy was higher than that taught by using Direct, Reading Thinking, Active (DRTA) strategy, (2) the students' achievement in reading comprehension with high self-regulation was higher than that low self-regulation, and (3) there was an interaction between teaching strategies and selfregulation on the students' achievement in reading comprehension. The population of this research was the students in grade XII of Madrasah Aliyah Negeri Sipirok of 2016/2017 academic year. There were 63 students as samples of this research by applying cluster random sampling technique. The instruments of this research were reading comprehension test and questionnaire sheet. The data were analyzed using ANOVA at the level of significant $\alpha=0.05$. The result of the data analysis proved that: (1) the students' achievement in reading comprehension taught by using RAPP strategy was higher than the students were taught by using DRTA strategy (2) the students' achievement in reading comprehension with high self-regulation was higher than the students were given low self-regulation, (3) there was interaction between teaching strategies and selfregulation. The students' achievement in reading comprehension is influenced by teaching strategies and self-regulation.
\end{abstract}

Keywords: teaching strategies, self-regulation, reading comprehension

How to Cite: Irmayanti (2017). The Effect of Teaching Strategies and Self-Regulation on Students' Reading Comprehension. Jurnal Linguistik Terapan Pascasarjana Unimed, 14(3): 223232

ISSN 2407-7410 


\section{INTRODUCTION}

Reading is an essential skill for all students at all levels. Reading arguably the most essential skill for success in all educational context, remain a skill of paramount importance as we create assessment of general language ability (Brown, 2006:185). Reading also takes important role in academic succession.

Lesson books contain information supporting them in understanding the lesson that they are studying. Want or not, students have to read those books to get knowledge. A student who is a good reader is more likely to do well in school and pass exams than that who is a weak reader.

Educational Unit Curriculum 2006 about standard competence in reading states that student are expected to be able to comprehend especially to identify, compare, interpret the meaning of interpersonal and transactional written text formally as well as informally in the forms of narrative, explanation, discussion and review in the context of daily life. It means that in reading skill, students are expected to be able to get some knowledge and information and understand the context explained in the text. Students must be able to get a considerable amount of information from a text.

Some studies; Hagaman and Reid, 2008; Munro, 2008; Blume, 2010; Hagaman, Kati, and Reid, 2012; Halterman, 2013; Dahlia, 2014; N Veronika, 2015 and Yunitasari, 2015 showed that students' reading comprehension was still low. Studies by indicated that the students are still difficult to comprehend the reading text. The study proves that the ability of Indonesian students' achievement in reading comprehension is lower than the International Standard. PIRLS (Progress in International Reading Literacy Study) is an international study that observes the reading ability of the students in the world.The result shows that Indonesian students have the 42 rank of 45 countries in the world (PIRLS,2012). This study supported by PISA (Programme for International Students Assessment) and OECD (Organization of Economic Co-operation and Development) on 2012 indicated that Indonesian students in 64 rank from 65 countries with 369 reading score (OECD, 2014: 5-7).

Based on the writer's experience in her teaching practice in MAN Sipirok, the students have lack interest in reading. The teacher uses Direct Reading Thinking Activity strategy (DRTA). She asked the students to examine text by looking at the title, illustrations, and the first few pages, and then make prediction what the text would be about. Subsequently, they read the text and confirmers or disconfirm their prediction read the passage and to search main idea. However, one thing that needs to be highlighted is that the teacher seemed not teach them how to monitor their comprehension individually during reading. Working on the questions after reading seemed not enough to consider whether the students really understood or really get the meaning upon the text. The strategy makes the students feel meaningless and cannot comprehend the text.

The low ability in reading comprehension can be caused by many factors; internally and externally. Internally means the factor known which come from the students themselves (Kahayanto, 2005:13), or usually known as personal factors, the factors has existed inside the readers. This factors dealt with age, attitude, learning style, interest, intelligence, talent, background knowledge, and 
including self-regulation. Externally means the factor which come from outside the readers. This factor is caused by curriculum, teaching media, teaching materials, environment, and teaching strategies.

There are many kinds of teaching strategies. In this study the researcher only take two strategies RAPPS (Read, Ask, Put and Paraphrasing Strategy), DRTA Strategy (Direct Reading, Thinking Activity Strategy), and self regulation which are considered suitable for reading comprehension because these strategies appropriate for solving the problem that students encounter.

The RAPP strategy focuses attention on the main idea and key details within paragraphs of a passage and active engagement with the text by rephrasing the main idea and details into a student's own words. The students should carefully read the text, think about the text, and then transfer author's message into their own words. By using their own words, it can help students to make sense of what they read, to monitor comprehension by themselves, and to remember the main idea and the details in long term memory.

To know the relationship between teaching strategies and self-regulation, some researchers (Oruc, Arslan 2016 ; and Hoyt, 2016) have reported findings to the favor of using teaching strategies and self-regulation on reading comprehension. Oruc, Arslan (2016) in their research about The Impact of Self-regulated Learning on Reading Comprehension and attitude towards Turkish Course and Metacognitive Thinking, have found that self -regulated learning significantly increased the reading comprehension and metacognitive thinking skills of the students in experimental group, by depending on the qualitative data it was found yhat the students in the experimental group used selfregulated learning skills while studying. While Hoyt, 2016, The Effect of Self-Regulated Strategy Development on Reading Comprehension, found that self-regulated strategy significantly improves how students with severe reading comprehension problems understand what they have read.

In carrying out the research, it is necessary to state the objectives of the study clearly. So, the objectives of this study is: if the students' reading comprehension taught by RAPPS is significantly better than DRTA strategy?

\section{RESEARCH METHOD}

This research was conducted by applying experimental design. Ary et al (2010:22) said that Quantitative is research that used statistical technique to understand and explain phenomena. Experimental research involved a study of the effect of the systematic manipulation of one variable on another variable. There were three variables in this study, they were two independent variables, moderator variable, and dependent variable. The independent variables in this study were RAPP Strategy and DRTA Strategy. The moderator variable is students' self-regulation which classified into high and low self-regulation. The dependent variable was the students' reading comprehension.

The research was conducted in MAN Sipirok Tapanuli Selatan District.The population of this research was all the students in the grade XII academic year 2016/2017. The researcher chose MAN 
Sipirok because the researcher wanted to know the effect of applying the RAPP and DRTA strategies and students' self-regulation in reading comprehension at that school. They were two classes were chosen in this study as the sample.

Knowing the students' self-regulation and the effect of the teaching strategies on students' reading comprehension, self regulation questionnaire and reading test as instruments applied for collecting data.

The instrument for collecting data in this study were reading comprehension test and selfregulation questionnaire. In this study, the data of reading comprehension collected by using multiplechoice test consists of 60 items with four options in each items and in three different genres (narrative, explanation, and discussion).

To find the students' self-regulation, the data collected by using questionnaire from selfregulation for students are taken from Pintrich et.al ( 1991). This questionnaire has been used to investigate students' motivation and value beliefs and their anxiety on the test. The type of questionnaire in this study was Liker-Scale.

The research design in this study was a $2 \times 2$ factorial design. Factorial design was methods of manipulating two or more variables simultaneously to study independent effect of each variable on the dependent variables as well as the effects for interactions among the several variables (Ary, 2010). This design compared two teaching strategies: RAPP strategy and DRTA strategy, and selfregulation. The research method applied to find out the teacher's treatment in the classroom to increase students' achievement.

The students were divided into two groups, namely the group taught by using RAPP Strategy and taught by using DRTA Strategy. The design could be seen in the the following Table 1 .

Table 1. Factorial Research Design

\begin{tabular}{|c|l|l|}
\hline Teaching Strategies & \\
Self-Regulation (B) & $\begin{array}{l}\text { RAPP } \\
\text { Strategy } \\
\left(\mathrm{A}_{1}\right)\end{array}$ & $\begin{array}{l}\text { DRTA } \\
\text { Strateg } \\
\text { y }\left(\mathrm{A}_{2}\right)\end{array}$ \\
$\begin{array}{c}\text { Low Self- } \\
\left.\text { Regulation( } \mathrm{B}_{1}\right)\end{array}$ & $\mathrm{A}_{1} \mathrm{~B}_{1}$ & $\mathrm{~A}_{2} \mathrm{~B}_{1}$ \\
\hline $\begin{array}{c}\text { High Self- } \\
\text { Regulation }\left(\mathrm{B}_{2}\right)\end{array}$ & $\mathrm{A}_{1} \mathrm{~B}_{2}$ & $\mathrm{~A}_{2} \mathrm{~B}_{2}$ \\
\hline
\end{tabular}

Note:

A1B1 : Students who have high self-regulation and are taught by RAPP Strategy

A1B2 : Students who have low self-regulation and are taught by RAPP Strategy

A2B1 : Students who have high self-regulation and are taught by DRTA Strategy 
A2B2 : Students who have low self-regulation and are taught by DRTA Strategy

Before two ways ANOVA was conducted, there are two requirements for the analysis: normality and homogeneity. Normality test uses Liliefors test and homogeneity test uses Barlett test. If there is interaction between both independent variables toward dependent variable from the result of the Fobserved analysis, so the next analysis using Tuckey-test would be done because the number of the research sample of each cell in research design is the same.

\section{FINDINGS AND DISCUSSIONS}

The data of students`achievement in reading comprehension were collected in every interaction between teaching strategies and self-regulation which obtain the highest and lowest scores, mean, and standard deviation. The values can be seen in Table 2 .

\begin{tabular}{|c|c|c|c|c|c|c|}
\hline \multicolumn{7}{|c|}{ Table 2. The Result of Descriptive Statistics } \\
\hline \multirow{2}{*}{\multicolumn{2}{|c|}{ Variabel }} & \multirow{2}{*}{ Statistic Sources } & \multicolumn{2}{|c|}{$\begin{array}{c}\text { Teaching Strategies } \\
\text { (A) }\end{array}$} & \multirow{2}{*}{ Total } & \multirow{2}{*}{$\begin{array}{c}\text { Gap } \\
\text { percentage }\end{array}$} \\
\hline & & & $\begin{array}{l}\text { RAPP } \\
\text { (A1) }\end{array}$ & $\begin{array}{c}\text { DRTA } \\
\left(\mathrm{A}_{2}\right)\end{array}$ & & \\
\hline \multirow{9}{*}{ 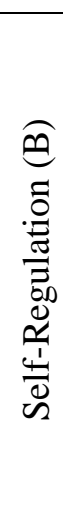 } & LowSelf- & Number of Samples & 11 & 10 & 21 & $9.09 \%$ \\
\hline & Regulation $\left(\mathrm{B}_{1}\right)$ & Average & 76.09 & 77.1 & 76.57 & $1.31 \%$ \\
\hline & & Standard Deviation & 2.02 & 2.88 & 2.46 & $29.86 \%$ \\
\hline & \multirow{3}{*}{$\begin{array}{l}\text { High Self- } \\
\text { Regulation }\left(\mathrm{B}_{2}\right)\end{array}$} & Number of Samples & 11 & 10 & 21 & $9.09 \%$ \\
\hline & & Average & 83.55 & 79.6 & 81.67 & $4.73 \%$ \\
\hline & & Standard Deviation & 1.29 & 2.27 & 2.69 & $43.17 \%$ \\
\hline & \multirow{3}{*}{ Total } & Number of Samples & 22 & 20 & 42 & $9.09 \%$ \\
\hline & & Average & 79.82 & 78.35 & 79.12 & $1.84 \%$ \\
\hline & & Standard Deviation & 4.16 & 2.83 & 3.62 & $31.97 \%$ \\
\hline \multirow{2}{*}{\multicolumn{2}{|c|}{ Gap Percentage }} & Average & $8.93 \%$ & $3.14 \%$ & $6.24 \%$ & \\
\hline & & Standard Deviation & $36.14 \%$ & $21.18 \%$ & $8.55 \%$ & \\
\hline
\end{tabular}

It can be concluded that the Score, Median, and, Standard Deviation that is reached by the students who are taught by RAPP srategy is higher than students are taught by

DRTA strategy.The students' achievement in reading comprehension with high selfregulation taught by using RAPP strategy had average $(\bar{X})=83.55$ and $\mathrm{SD}(S)=1.29$. The highest scores were 85 and the lowest scores were 82 ; Media $\left(\mathrm{M}_{\mathrm{e}}\right)=84.00$. The frequency distribution of the students' achievement in reading comprehension with high self-regulation taught by using RAPP strategy. It means that RAPP strategy is more effective than DRTA strategy in teaching reading comprehension. 
Before the research data were analyzed by using two-way Analysis of Variance (ANOVA). Normality and Homogeneity of the data were test Normality test aims at showing the sample data of the population is normality distributed. The technique used is Liliefors-test.

Based on the calculation result, the data obtained for each group is is presented in Table 3.

Table 3. Result Normality Testing of Reading Comprehension with Kolmogorov Smirnov Test

\begin{tabular}{|c|c|c|c|c|}
\hline \multirow{2}{*}{ Groups } & \multicolumn{2}{|c|}{ Kolmogorov-Smirnov } & \multirow{2}{*}{ Conclusion } \\
\cline { 2 - 4 } & Statistic & df & Sig. & \\
\hline RAPP & 0.164 & 32 & 0.028 & Normal \\
\hline DRTA & 0.163 & 31 & 0.035 & Normal \\
\hline $\begin{array}{c}\text { High } \\
\text { Regulation }\end{array}$ & 0.146 & 32 & 0.083 & Normal \\
\hline $\begin{array}{c}\text { Low } \\
\text { Regulation }\end{array}$ & 0.154 & 31 & 0.059 & Normal \\
\hline
\end{tabular}

a. Lilliefors Significance

Correction $(0.025)$

Homogeneity test was used to find out the variance of the data is homogenous or not. The condition of data groups, the variance must be relative the same. To determine the homogeneity variance of the whole students' achievement in reading comprehension with high and low selfregulation taught by using RAPP and DRTA strategies used Lavene Test. The summary of test could be seen on Table 4.

Tabel 4. Homogeneity Test

\begin{tabular}{|c|c|c|c|c|c|c|}
\hline Component & $\begin{array}{c}\text { Statistics } \\
\text { Sources }\end{array}$ & $\begin{array}{c}\text { Levene } \\
\text { Statistic }\end{array}$ & df1 & df2 & Sig. & Conclusion \\
\hline $\begin{array}{c}\text { RAPP- } \\
\text { DRTA }\end{array}$ & $\begin{array}{l}\text { Based } \\
\text { on Mean }\end{array}$ & 0.694 & 1 & 61 & 0.408 & Homogen \\
\hline
\end{tabular}

Based on the whole student' achievement test scores, the mean of each matrix has group descriptions on each cell. Analysis variance was used Anava $2 \times 2$, so here the requirements testing used to find the interaction between teaching strategies and self regulation on the Table 5 .

Table 5. Summary on Calculation of Two Way Anava

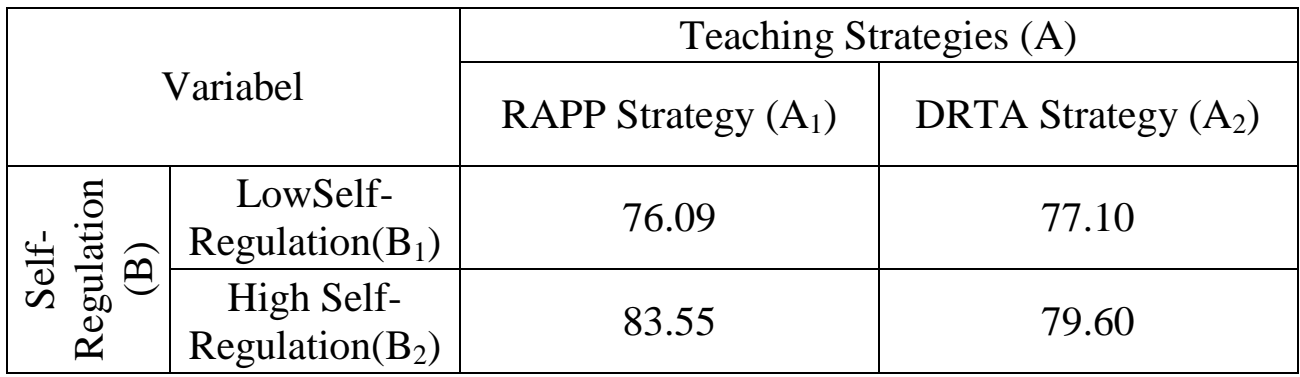


Based on the result study, the whole students' achievement in reading comprehension taught by using RAPP strategy had average scores 80.09; and the students achievement taught by using DRTA strategy only got average score 77.42 .

The students' achievement in reading comprehension taught by using RAPP strategy was better than DRTA strategy because this teaching strategy developed by constructivism theory, where the students gave the freedom to construct their knowledge by interaction their environment so it could be improved their ability to comprehend their reading and understanding the goal of the reading in detail. The knowledge to Read, Ask, Put, and Paraphrasing was not only something to imitate from the real life. RAPP strategy was the process of information creatively, convergent, and use language ability. Principally RAPP strategy tried to increase the students' ability to read, ask, put and paraphrasing the goal of reading itself.

DRTA strategy was different from RAPP strategy, where the process of information got by helping from teacher. So to increase the students' creativity on reading comprehension were done conventionally. The teachers had roles to determine the reading goals given. The teachers also as facilitator, to help the students to understand the lesson by knowing the strength and the weakness of students problems.

The differences between the students' achievement in reading comprehension with high selfregulation taught by using RAPP strategy and DRTA strategy, the average of reading comprehension achievement 83.55 and 79.60. Based on the Tuckey Test sig. $=0.001<$ probability $\alpha=0.05$. It prove that the difference of reading achievement significant on the level of $\alpha=0.05$. It means that RAPP strategy is better to enhance students' achievement in reading comprehesion than DRTA strategy. That statement can be accepted because RAPP strategy lets the students to look for the information based on their needs. It means that, this strategy makes the students to engaged in reading comprehension through questioning, and paraphrasing to increase their comprehension of the materials. From questioning and paraphrasing, students process information for better understanding of what they read; focused on the main idea and key detail within paragraphs of a passage; engaged with the text by rephrasing by main idea and details into a student's own words and the students become independent reader and more active, more confident retelling a sentence in their own words.

From the explanation above, it clear that the students who had taught with RAPP strategy were higher than the students who had taught with DRTA strategy, they were influenced some factors : (1) the increasing of students creativity in finding the solution of their problem in reading comprehension; (2) the increasing students self-learning; (3) the increasing students' knowledge to overcome their problem in reading comprehension; (4) to create actively, critically, and creativity in solving their problem. 


\section{CONCLUSIONS}

Based on the data analysis, some conclusions are derived from meaningful of discussion of this study in the following there is significant interaction between teaching strategies and selfregulation on the students' achievement in reading comprehension. The students' achievement in reading comprehension is influenced by teaching strategies and self-regulation. The high selfregulation students showed significant effect on their reading comprehension achievement if they were taught by using RAPP strategy while low self-regulation students showed significant effect on their reading comprehension achievement if they were taught by using RAPP strategy.

\section{REFERENCES}

Arikunto, S. 2008. Prosedur Penelitian: Suatu Pendekatan Praktek. Edisi Revisi V. Jakarta: RinekaCipta.

Blume, C. D. 2010, RAP: A Reading Comprehension Strategy for Students with Learning Disabilities (Master's Thesis, University of Nebraska, Lincoln, NB), Retrieved from http://digitalcommons.unl.edu/cgi/viewcontent.cgi?article $=1061 \&$ context=cehdiss.

Brown, H. D. 2006. Principles of Language Learning and Teaching: 5th Ed. London: Longman Group.

Dahlia. 2014. The Effect of Using Read, Ask Questions, and Put into Your Own Words (RAP) Strategy toward Reading Comprehension of the Second Year Students at Senior High School YLPI Pekanbaru. Pekanbaru: UIN Suska Riau.

Hagaman, J. L., Casey, K. J., \& Reid, R. (in press). The effects of the paraphrasing strategy on the reading comprehension of young students. Remedial and Special Education.

Halterman Jr, Terry, 2013, Effects of RAP Paraphrasing and Semantic-Mapping Strategies on the Reading Comprehension of English Learners and Fully-English-Proficient Students with Mild-to-Moderate Learning Disabilities (Doctoral Dissertation, University of San Francisco), Retrieved from http://repository.usfca.edu/diss.

Hoyt, Lisa R. 2016, The Effect of Self-Regulated Strategy Development (SRSD) on Reading Comprehension for Secondary Students with Emotional and Behavioural Disabilities (Doctoral's dissertation, University of Washington), 2010.

OECD, Comparing countries' and economies' performance, 2014. Retrieved from http://www.oecd.org/pisa/46643496.pdf.

Oruc, Ayse., Arslan, Ali, 2016, The Impact Self-regulated Learning on Reading Comprehension and Attitude towards Turkish Course and Metacognitive Thinking, Volume 11 (8), pg. 523-529. Accessed from http://www.academicjournal.org/ERR on April 23, 2016.

PIRLS, PIRLS International Results in Reading [Adobe Digital Editions version], 2012. Retrieved from http://timssaandpirls.bc.edu/pirls2012/downloads/P11_IR_FullBook pdf 18

Sari, Yunita, 2015, Improving Reading Comprehension of The Eight Grade Students at SMPN 15 Yogyakarta through RAP Strategy in Academic Years of 2014/2015. 
Arikunto, S. 2008. Prosedur Penelitian: Suatu Pendekatan Praktek. Edisi Revisi V. Jakarta: RinekaCipta.

Ary, D. et al. 2010. Introduction to Research in Education. (Eighth Edition). Canada Wadsworth. Best, J.W. 1981. Research in Education. New Jersey: Prentice-Hall, Inc

Blume, C. D. 2010, RAP: A Reading Comprehension Strategy for Students with Learning Disabilities (Master's Thesis, University of Nebraska, Lincoln, NB), Retrieved from $\mathrm{http} / / /$ digitalcommons.unl.edu/cgi/viewcontent.cgi?article=1061\&context=cehdiss

Brown, H. D. 2006. Principles of Language Learning and Teaching: 5th Ed. London: Longman Group.

Dahlia. 2014. The Effect of Using Read, Ask Questions, and Put into Your Own Words (RAP) Strategy toward Reading Comprehension of the Second Year Students at Senior High School YLPI Pekanbaru. Pekanbaru: UIN Suska Riau

Halterman Jr, Terry, 2013, Effects of RAP Paraphrasing and Semantic-Mapping Strategies on the Reading Comprehension of English Learners and Fully-English-Proficient Students with Mildto-Moderate Learning Disabilities (Doctoral Dissertation, University of San Francisco), Retrieved from http://repository.usfca.edu/diss

Hagaman, J. L., Casey, K. J., \& Reid, R. (in press). The effects of the paraphrasing strategy on the reading comprehension of young students. Remedial and Special Education

Hoyt, Lisa R. 2016, The Effect of Self-Regulated Strategy Development (SRSD) on Reading Comprehension for Secondary Students with Emotional and Behavioural Disabilities (Doctoral's dissertation, University of Washington), 2010

Munro, J. 2008. Teaching paraphrasing improves reading comprehension. Unpublished manuscript.

OECD, Comparing countries' and economies' performance, 2014. Retrieved from http://www.oecd.org/pisa/46643496.pdf

Oruc, Ayse., Arslan, Ali, 2016, The Impact Self-regulated Learning on Reading Comprehension and Attitude towards Turkish Course and Metacognitive Thinking, Volume 11 (8), pg. 523-529. Accessed from http://www.academicjournal.org/ERR on April 23, 2016

PIRLS, PIRLS International Results in Reading [Adobe Digital Editions version], 2012. Retrieved from http://timssaandpirls.bc.edu/pirls2012/downloads/P11_IR_FullBook pdf 18

Sari, Yunita, 2015, Improving Reading Comprehension of The Eight Grade Students at SMPN 15 Yogyakarta through RAP Strategy in Academic Years of 2014/2015 